Универзитет у Београду, Филозофрски фракултет Одељење за етнологију и антропологију, Београд

DOI 10.5937/kultura1963097P

УДК 821.111(73).09 Лиготи Т.

141.22:821.111(73) Лиготи Т.

оригиналан научни рад

\title{
ОНИРИННО ПОДРИВАНЕ СТВАРНОСТИ
}

\section{НАТПРИРОДНА СТРАВА И НИХИЛИЗАМ ТОМАСА ЛИГОТИЈА}

Сажетак: Просветитељьки идеал света којим у изелости влада људски разум и који је потпуно устројен универзалним мерилима рационалности једнако је оспораван и брањен откако је заживео у интелектуалној традицији Европе. Вера у разум као у ексклузивно својство људског ума кадро да репродукује аутентичну слику стварности, на Западу се брзо показала дискутабилном како из угла филозофије, тако и уметности, али и појединих научних дисциплина (пре свих, психологије и антропологије). У оквирима савремене книжевне продукиије, један од највећих противника просветительске замисли о разумом спознатљивој природи стварности је хорор писаи Томас Лиготи. За овог аутора, „свет какав јесте" има мало или нимало везе са рационалном свешћу, а далеко више са садржајима које нам сугеришу најдубљи ираџионални страхови оличени у грозничавим визијама и кошмарним сликама. Засновавщи свој лични и уметнички светоназор на инверзији устаьених представа о стварном, Лиготи ствара специфичну врсту субверзивне прозе: наиме, ону коју свет лишава вишег смисла и тиме оспорава човеку сваку могућност утехе. Да ли ова крајюа безилузорност индивидуи оставља икакво место за самостално делање (субверзивно или не) једно је од основних питања на које ћу настојати да одговорим у овом раду.

Кључне речи: Томас Лиготи, натприродна страва, појединац, стварност, кошмар, нихилизам

Натприродна страва има много лица. Она најшире позната и већ донекле овештала налазе се у форми вампира, вукодлака и ходајућих лешева. Она нешто опскурнија и мање типска, 
узимају обличја чудовишта из дубоког свемира, демона из тајанствене прошлости, опседнутих људи, демонизоване деце, језивих сила што се више осећају него што могу да се разазнају чулима, древних клетви, уклетих здања или чудних, граничних простора који служе као капије за друге димензије, често још кудикамо горе од оне коју смо игром случаја или потком судбине напустили. Бројна лица натприродног ужаса могу се, према томе, најчешће наћи негде другде или у неком/нечему другом, тачније у једној равни која и јесте и није стварна, која није ни близу ни далеко, али која је у сваком случају удаљена од нас бар онолико колико је ноћна мора удаљена од јаве несумњивим осећајем будности.

Мало ко је срце и душу натприродне страве настојао да потражи у самој сржи стварности којом смо окружени. Један од таквих аутора је Томас Лиготи (Thomas Ligotti). Овај писац неколицине збирки приповедака ${ }^{1}$, једне књиге есеја ${ }^{2}$ и једног романа ${ }^{3}$, настављач је, како сам истиче, књижевне традиције коју су у хорор прози установили Едгар Алан По и Хауард Филипс Лавкрафт ${ }^{4}$, двојица писаца специфичних по томе што су пронашли врло упечатљиве и особене начине да поетизују утисак страве у прозном тексту. Слично Поу и Лавкрафту, и Лиготи има разрађен, доследан и врло песимистичан поглед на свет, који служи као концептуална подлога многим његовим хорор приповеткама. Овај поглед на свет ослања се на филозофију радикалног нихилизма и

1 Међу његовим најрепрезентативнијим збиркама прича су Songs of a Dead Dreamer (1986), Grimscribe: His Lives and Works (1991 - код нас преведена 2017. године као Писар таме: Живот и дела, у издању Орфелин издаваштва), Noctuary (1994) и Teatro Grottesco (2006).

2 Реч је о неакадемској, али учењачким језиком и схоластичким приступом израђеној студији из филозофије песимизма и нихилизма, објављеној 2010. године, под насловом The Conspiracy Against Human Race.

3 My Work is Not Yet Done (2002 - код нас преведена 2014. године као Недовриени посао у издању IP Book-a).

4 Поов утицај на Лиготија, а Лавкрафтов нарочито, оставили су на овог писца утисак који се најверније дочарава следећим његовим цитатом: „Да није било Лавкрафта, не верујем да би било ко други ко је икада живео могао да се назове моделом писца хорора. Он је пришао најближе томе да постане све оно што би неко могао да замисли о некоме ко је живот спознао у свој његовој огавности и ко је час славио а час кудио овакво стање ствари, а затим од тога начинио душу своје уметности. $(\ldots)[Р]$ етко је, ако је икада уопште, Лавкрафт одступао од онога што га је учинило моделом хорор писца који живот опажа у његовој огољеној гнусности и који је од те перцепције начинио основу онога што јесте”. Лиготи у: Ognjanović, D. (2015) The Greatest Old One, Rue Morge 161, стр. 18. 
могао би да се окарактерише као уједно морално и метафизички нихилистичан. ${ }^{5}$

У овом раду, усредсредићу се на Лиготијево схватање стварности и човековог места у свету. Разумевање односа према стварном и нестварном је од кључног значаја за пажљивију контекстуализацију Лиготијевих нихилистичких ставова у ширем светоназору овог писца, ставова за које би, због уобичајеног асоцирања нихилизма са анархизмом ${ }^{6}$, било очекивано да располажу извесним субверзивним потенцијалом или да испољавају неку форму друштвене критике. Међутим, управо због својих нихилистичких уверења, како ћу у овом тексту настојати да покажем, Лиготи је у основи незаинтересован за друштвено-политички ниво стварности, при чему никаква промена друштвеног устројства на боље или на горе, како његови прозни ставови сугеришу, не би могла да битно утиче на његову крајње негативну дијагнозу људског стања нити да доведе до човековог ослобођења од погубног утицаја сила које, у метафизичком смислу, кроје стварност. Дејству стварности, чији се опскурни, закулисни механизми налазе иза равни појавног, немогуће је, према његовој замисли стати на пут, али је могуће са њом се суочити и упусти се у неку врсту имагинарне игре на пољу нестварног. Ова игра појединцу не доноси трајно олакшање, али му обезбеђује бар тренутно задовољство произашло из увида у извесне истине о диспозицијама и последњим принципима света: истине које појединца постепено удаљавају од опсена „лажне” и примичу домену „непатворене” стварности.

У циљу културне контекстуализације Лиготијевих нихилистичких убеђења, у првом делу текста ћу указати на неке додирне тачке Лиготијеве перцепције света са основама будистичке доктрине и Шопенхауеровог филозофског концепта света-као-воље, док ћу у другом делу рада говорити о моралној димензији Лиготијевог нихилизма упоређујући је (у најосновнијим цртама) са Ничеовом. У закључку ће бити речи о томе да кретање од ,лажи” ка „истини” о свету, како га бар Лиготи схвата, не може бити колективно, већ искључиво индивидуално, због чега оно буди осећај страха, па је књижевна форма хорор приче савршено прикладан медијум за његов метафорички опис, као и за сугерисање, путем низа пажљиво грађених слика, његових (бес)коначних, језовитих импликација.

5 Видети интервју са Лиготијем на интернет страници: https://wonderbooknow.com/interviews/thomas-ligotti/

6 Borg, M. B. (1988) The Problem of Nihilism: A Sociological Approach, Sociological Analysis, vol. 49: 1, Oxford: Oxford University Press, pp. 1-16. 


\section{Стварност, кошмар и ништавило}

Нихилизам заступа позицију да вредности не постоје и да живот нема никакав смисао. Ова филозофска позиција може проистицати из неког фундаменталог увида, или скупа увида у природу стварности, као, рецимо, у будизму или у Шопенхауеровој филозофији које се обе управљају начелима метафизичког нихилизма. ${ }^{7}$ На пољу моралних категорија, с друге стране, нихилистички назори представљају људске вредности као илузорне или лишене било каквог објективног утемељења, због чега се налазе на мети оштре критике у бројним епистемолошким дебатама. ${ }^{8}$

Лиготијева перцепција света, како ћемо видети, ослања се на будистичку, односно на прву од четири племените истине будизма, с тим што децидно одбацује будистички идеал просветљења ${ }^{9}$. У метафизичком спектру значења, будистичка доктрина пропагира начело savram duhka - опречно начелу угодности (sukhi). Према овој дијагнози људског стања, све је патња, а чак је и срећа носилац узнемирујуће жеље која човеку наноси бол, налажући му да се стара о томе да његова срећа траје (што је у основи немогуће, будући да ништа не траје више од трена). У животу, дакле, увек постоји нешто што није како ваља, почевши од рођења, преко старости, до болести и смрти. Сједињење с оним кога не волимо изазива патњу, као што је ствара и раздвојеност од онога кога волимо, односно непостизање онога што желимо. Све је бол и обмана: опсена патње једнако као и патња због опсене.

Овом темељном незадовољству, према будистичком учењу, извор се може наћи у жељи која је манифестована кроз три варијетета: жеђ за угодношћу, односно за телесним задовољством; жеђ за постојањем и трајањем, односно нагон за опстанком; и жеђ за непостојањем, односно искушење страственог и депресивног самоубиства. Сви ови варијетети жеље нас осуђују да прелазимо с објекта на објект и да трансмигрирамо - како се задовољење жеље мења - у незадовољење које рађа нову жељу, а она мотив за обновљено деловање; и тако унедоглед. Ови циклуси несталности носиоци

7 Doomen, J. (2012) Consistent Nihilism, The Journal of Mind and Behavior, Vol. 33, No. 1/2, New York: Institute of Mind and Behavior, Inc. pp. 103-107.

8 Pišev, M. (2018) Islam, relativizam i nauka, Beograd: Filozofski fakultet i Dosije studio, str. 7-89.

9 Ognjanović, D. Tomas Ligoti: Iz dubine najcrnjeg ambisa, u: Pisar tame: život i dela (2017), Novi Sad: Orfelin izdavaštvo, str. 281. 
МАРКО ПИШЕВ

су закона кармана чије се последице очитавају у струјањима егзистенције, тачније у самсари или трансмиграцији. ${ }^{10}$

Да би се циклус самсаре привео крају, потребно је укинути жељу. С укидањем жеље, нестаје и патња, која није ништа друго до исход осујећених прохтева. Умеће укидања жеље, које се између осталог постиже овладавањем духовним техникама будизма, резултује нирваном, престанком егзистенције, односно гашењем или потпуним растварањем индивидуалне свести у ништавилу, које је уједно и коначни циљ будистичке доктрине.

Метафизички нихилизам изворног будизма не може се, дакле, назвати апсолутним зато што препознаје извесне принципе који владају светом, односно нашом интерсубјективно дељеном стварношћу, и афирмише их. Ти принципи наликују решетки у кавезу, док је кључ који нас изводи из тог кавеза - просветљење у ништавилу. Аналогно овим оквирима, и Лиготијев доживљај света, премда радикалан, не може се окарактерисати као апсолутно нихилистичан: иако приватно верује да не постоји ништа иза „драперије наше пути"11, овај аутор истовремено настоји да уметничким средствима дочара утисак да нешто тајанствено у залеђу физичке реалности и њених представа ипак постоји. Дакле, Лиготи негира метафизичку есенцију човека, али не оспорава могућност метафизичке суштине стварности. Да бисмо разрешили овај привидни парадокс, потребно је да се осврнемо на основна филозофска начела Артура Шопенхауера која имају мноштво додирних тачака са Лиготијевим становиштима.

Снажно надахнута будистичким (као и хиндуистичким) концептима, филозофија Артура Шопенхаура инсистира на овде већ предоченој дијагнози људског стања, према којој свака индивидуална људска историја јесте - историја патње, с обзиром на то да је свачији живот непрекидни низ већих или мањих несрећа. Воља, коју Шопенхауер описује као ствар по себи, те која подупире и опредмећује сву појавност света, основни је извор те несреће, будући да она нема никакву сврху ни циљ; концепт воље за Шопенхауера напросто представља скривену и метафизичку силу на којој свет почива и која је изражена кроз индивидуалну и колективну вољу за постојањем, те кроз универзалне силе природе, које обезбеђују нашим емпиријским доживљајима релативно

10 Bugault, G. Mistika indijskog budizma, u: Enciklopedija mistika II svezak, priredila Davy, M. M. (1990), Zagreb: Naprijed, str. 178-179.

11 Видети интервју са Лиготијем на интернет страници https://www.ligotti. net/showthread.php?t=5 
стабилан и објективан квалитет. ${ }^{12}$ Према томе, његов светкао-воља метафизички је концепт, неспознатљив чулима и скривен у залеђу природе; али он уједно и чини природу могућом. Схваћен у терминима ултимативне стварности, он је недоступан свакој форми људске спознаје, сем оној за којом трагају мистици; спознаји заснованој, дакле, мање на рационално-филозофским, а више на интуитивно-езотеричним увидима као путоказима ка откривању коначних мистерија и скривеног смисла ствари ${ }^{13}$.

Човек и сва својства којима човек располаже, производ су, према Шопенхауеровим схватањима, света-као-воље. Али будући да творевине ове метафизичке суштине стварног као уосталом и стварност сама - немају никакав виши смисао, ни суштина човековог постојања, односно престанка егзистенције, не може се посматрати као одраз неког вишег смисла или поретка ствари. У том погледу, визуре Лиготија и Шопенхауера су компатибилне, јер и један и други сматрају да човек по себи не располаже метафизичком компонентом; људска индивидуа напросто обитава у реону стварног који не само што је непресушан извор патње, већ у његовим делатним оквирима све неминовно и води ка патњи. Стварност je, другим речима, носилац метафизичког начела, док је човек тог начела лишен, премда је способан да га назре изван себе самог и то оним аспектима интелекта који не укључују само пуко садејство чула и разума, већ обухватају и сва она емотивна стања и упливе ирационалног, одговорна за изградњу интензивног, свеобухватног и, бар у Лиготијевом случају врло радикалног, Weltschmerza.

Латентна димензија стварности чија метафизичка својства премашују капацитет људског разума постаје, за Лиготија, предмет човековог искуства у сновима, и то најпре у кошмарима. За овог аутора, само постојање је непрекидан и вечити кошмар а према његовом сопственом признању, тај став се налази у залеђу свега што је икада написао. ${ }^{14}$ У складу са начелом егзистенције као кошмара, Лиготи пренебрегава да пише о ономе што би могло да се назове објективним ужасима спољног света - о геноцидима, катастрофама, масовној глади, о политичком терору, слому екосистема... - већ је у целости фокусиран на унутрашње ужасе који на овај или онај начин опседају већину људи. Ово на први поглед

12 Šopenhauer, A. (1981) Svet kao volja i predstava, Beograd: Grafos.

13 Cross, S. (2013) Schopenhauer's Encounter with Indian Thought: Representation and Will and their Indian Parallels, Honolulu: University of Hawai'i Press, pp. 181-188.

14 Interview with Thomas Ligotti by Robert Bee, 10. 05. 2019. http://ligotti.net/ tlo/bee.html 
може да делује као ескапистички потез, али сагледамо ли га пажљивије, можемо констатовати да уметничко усредсређење на ирационалан страх који је више или мање латентан у свима нама и који нас на махове преплављује чак и онда кад не сањамо, није у функцији бега, већ у проналажењу скровишта од ужаса ,у самом срцу ужаса”. ${ }^{15}$

„Док ми вриштимо и цркавамо”, пише Лиготи, „историја облизује прст и окреће страницу." фира туробну слику света, колико успева да нагласи његову бескрајну равнодушност спрам људске патње. ,Човечанство је”, како аутор процењује, „осуђено на улогу пајаца”; а потом саркастично додаје: „Али унаоколо нема никога ко би нам се ругао." 17

Лиготи, како је већ речено, доживљава сву материјалну појавност, укључујући и човечанство у целини, без обзира на родну, класну или расну припадност појединаца, као кобну грешку, као низ бесмислених и врло несрећних случајности, којој само мислећа бића попут људи настоје да припишу некакав виши смисао. Људски род за Лиготија, аналогно првој од четири племените истине будизма, односно основним начелима Шопенхауерове филозофије, представља колективну жртву корумпираног савеза бола и задовољства, где су рај и пакао само различити одсеци исте чудовишне бирократије: „Између те две крајности постоји све што знамо или све што икада можемо сазнати." 18 У тренутку када човечанство стекне свест о сопственом кобном стању, људски ум, према Лиготијевом поимању ствари, доживљава расцеп. Једна половина свести се свим силама опредељује за одбрану удеса свесности и његово оправдање, јер оно „мора бити нечим оправдано да би се уопште могло трпети.”'19 Друга половина нам макар привидно омогућава да се боримо против властите пропасти и да у току те борбе уображавамо да нисмо апсолутне жртве. Један од метода човекове борбе против удеса стварности је, како Лиготи сматра, хорор књижевност: „Све ствари које нас виктимизују у природном животу могу да послуже као основа демонске насладе у измаштаном свету натприродног хорора". ${ }^{20}$

15 We Can Hide From Horror Only In The Heart Of Horror: Notes and Aphorisms by Thomas Ligotti, 10. 05. 2019. http://www.angwa.de/Ligotti/essay/ heartofhorror e.htm

16 Ligotti, T. (2012) Songs of a Dead Dreamer (e-book), p. 111.

17 Исто, стр. 111.

18 Исто, стр. 112.

19 Исто, стр. 111.

20 Исто. 
Сагледано из угла крајњих исхода људске егзистенције, човечанство је према Лиготијевом мишљењу посве егалитарно. За разлику од неких његових жанровских узора, Лавкрафта и Ејкмана, који су сваки на свој начин заступали одређену врсту елитизма - Лавкрафт са својим етничким предсрасудама ${ }^{21}$ и глорификацијом Нове Енглеске ${ }^{22}$, а Ејкман са својом апологијом империјализма ${ }^{23}$ и аристрократским презиром према концепту друштвене једнакости ${ }^{24}$ Лиготи, лично, у својим ставовима, као и у оквирима његове поетике, нема никаквих додирних тачака са заступништвом било чијих „урођених” права или промоцијом било какве „добре”, „проверене” друштвене традиције. За овог аутора, бол и несрећа стварног живота исувише су тужни и трагични да би се могли поднети. Штавише, у овим људским несрећама он не види никакву кохеренцију, никакву визију: „Као што је Марк Твен рекао, 'живот је само једна проклета ствар поврх друге.' Не желим да будем сведок овоме нимало више него што је то неопходно. Хоћу да се придружим мишљењу некога ко ће устати и рећи 'живот је само једна проклета ствар поврх друге', а не неком нацереном идиоту који ће представити ову чињеницу као облик порнографије зато што корпорација зна да може да искористи такве садржаје како би продала минуте за рекламе. Сви су свесни да је то тако. Сви знају да је то крајње гнусно. Свако је, мање или више, протува." 25

Будући да је из Лиготијевог угла „проклета штета” што органски живот на овој планети уопште постоји, наш аутор не оставља никаквог простора за могућност да се људска егзистенција учини подношљивијом, тако што би, примера ради, у свету могло бити више правде, више слобода, мање масовног уништења, симетричније прерасподеле добара и слично. Привилегије, права, моћ, економска добит, па и чулна уживања ништавни су пред невидљивим дејством латентне димензије стварности, „великим ревизором свега виђеног и

21 Које се релативно лако могу ишчитати из његове најпознатије приче, Зов Ктулуа, а још лакше из једне мање антологизоване и хваљене приповетке, под називом Ужас у Ред Хуку (преводи обе ове приче налазе се у антологији Некрономикон, чији је приређивач Дејан Огњановић, публикованој 2018. године од стране издавачког предузећа Орфелин).

22 Ognjanović D. nav. delo, str. 290.

23 Која је сугерисана каткад имплицитно, а каткад и изнесена експлицитно у његовој аутобиографији The Attempted Rescue (1966, London: Gollancz).

24 Aickman, R. Introduction, in: The 3rd Fontana Book of Great Ghost Stories, ed. Aickman, R. (1966), Glasgow: William Collins Sons \& Co. p. 7.

25 Nedal, A. Literature Is Entertainment Or It it Nothing: An Interview With Thomas Ligotti, 10. 05. 2019. http://ligotti.net/showthread.php?t=420 
МАРКО ПИШЕВ

невиђеног, познатог и непознатог" која сеже у свет и мења га, „прекрајајући сенке саме, премазујући чудним бојама наше дане и наше ноћи, мењајући дан у ноћ, да више не бисмо склопили ока и да бисмо сањали док смо будни."26

Стварност је у сваком тренутку подложна злоћудној мутацији из лошег у горе и не постоји духовна дисциплина, обредна пракса или магијска техника кадра да на било који начин те промене контролише, предвиди или спречи. Бог за Лиготија није мртав; он никада није ни постојао. Једино што у метафизичком смислу постоји јесте тама анимирана бескрајним кошмаром чија се својства и еманације устремљују на органски живот без икаквог докучивог циља или сврхе. У том смислу, Лиготи сумња у трезвену утеху да је хорор неки пролазан вишак свесности, морбидна слабост човекове природе; његов метафизички нихилизам, уместо тога, стоји иза помисли да је хорор уплетен у темеље реалности саме. ${ }^{27}$ Књижевност натприродне страве постаје, тако, у лиготијевском кључу, горка побуна против ,здравог” разума, у којој смрт, страх и лудило служе као методи ионако узалудне и на пропаст осуђене борбе против елементарних чињеница свеколике, па и људске, егзистенције.

\section{Ништавност људских екстраполачија}

Како смо се уверили у претходном одељку, Лиготи заступа концепцију људског искуства према којој је стварно неодвојиво од нестварног. Штавише, он сматра да хорор (привидно, елемент нестварног) постоји како унутар, тако и изван категорија људске свести, да је ужас нека врста метафизичке подлоге на којој све плута и која се не покорава ни људским ни природним, већ властитим законима. Аутономан и заповеднички, хорор је у основи стваран - штавише, стварнији од нас самих.

Ово метафизичко уверење има крупне последице по концептуализацију људских вредности и моралних стандарда. Уколико прихватимо мисаони систем заснован на (назовимо га тако) reductio ad horror слици света, из датог каузалног ланца, чија се почетна струна налази у равни недоступној човеку, нема и не може бити бега, јер овај узрочно-последични однос обухвата све што опажамо, све што осећамо, све што јесте. У складу са Лиготијевим метафизичким светоназорима, граница између добра и зла, онда, није повучена

26 Ligotti, T. (1994) Noctuary, New York: Carrol \& Graff, Inc. p. 76.

27 Santilli, P. (2007) Culture, Evil and Horror, The American Journal of Economics and Sociology, Vol. 66, No. 1, New Jersey: American Journal of Economics and Sociology, Inc. p. 179. 
у човековој врлини или друштвеним вредностима, већ у дубини људске спознаје о правом карактеру света. Будући да је свет зло, најмање зато што је темељно начело егзистенцијекао-кошмара у основи опречно постизању било каквог животног задовољства или трајне среће, једини живот вредан живљења јесте живот проведен у блаженом незнању о последњим принципима или најскривенијим својствима света. Али, одатле не следи да је могуће извести било какав скуп нормативних вредности, зато што живот проведен у незнању може бити било какав живот, па и морално најкорумпиранији и духовно најнижи облик постојања, докгод оно појединцу обезбеђује ментално скровиште од латентне и по људску добробит погубне - димензије стварног.

Проблем с вредностима настаје, према томе, онда када крећући се од метафизичких полазишта, тврдимо да је живот у основи патња и да никакво истинско задовољство и срећа нису могући. Зато што живот не доноси трајно одсуство бола, већ напротив, непрестано изнова репродукује нашу патњу, било би, дакле, боље да свет не постоји. Можемо, упоредне перспективе ради, скренути пажњу на чињеницу да је ову песимистичку формулу прихватио и Фридрих Ниче, ослањањући се на Шопенхауерове идеје о свету-као-вољи. ${ }^{28}$ Али Ниче је, за разлику од Лиготија, дошао до различитих закључака о вредностима. ${ }^{29}$

Морални нихилизам у Ничеовој филозофији (па у извесном смислу и код Лиготија) не тиче се толико филозофског суда да су вредности до којих држимо по себи промашене, већ да је због тога што је свет такав какав јесте, те вредности немогуће остварити. Имплицитне премисе нихилизма код Ничеа произлазе из идеје о смрти Бога, као и из директних последица те идеје, које налажу да се могућност истине чиje је средиште Бог више не може узети заозбиљно, дакле да је Бог дискредитован не само као натприродно биће, већ и као господар читавог једног метафизичког домена над којим, према устаљеној религијској перцепцији, суверено влада, ${ }^{30}$ Ипак, сама констатација да је Бог мртав не подразумева урушавање вредности, чак ни оних утемељених на егзегезама монотеистичких скриптуралних извора; јер, све и да је вредности немогуће остварити на оностраном плану, шта људска бића спречава да то покушају да учине у сфери

28 Clark, M. (2012) Suffering and the Affirmation of Life, Journal of Nietzsche Studies, Vol. 43, No. 1 University Park: Penn State University Press, p. 89.

29 Niče, F. (2012) Volja za moć: pokušaj preocenjivanja svih vrednosti, Beograd: Dereta

30 Reginster, B. (2006) The Affirmation of Life: Nietzsche on Overcoming Nihilism, Cambridge: Harvard University Press, p. 41. 
МАРКО ПИШЕВ

овостраног? Имајући ову дилему у виду, Ниче је концепцији нихилизма произашлој из тезе о смрти Бога додао још једну, скривену премису: наиме, ону да је неопходно да пригрлимо вредности које оспоравају живот; и штавише, да их установимо као наше највише вредности. ${ }^{31}$

Ова замисао није страна Лиготију. Како је претходно већ наглашено, књижевност натприродне страве за овог аутора представља метод борбе против удеса стварности, борбе која је по себи вреднија и далеко субверзивнија од апологетике тог удеса, упркос чињеници да је унапред осуђена на пропаст. Лиготи, дакле, прихвата вредности које негирају живот, најмање утолико што их користи да би уметничким средствима морбидно исмевао људско стање; хорор аутор, како га Лиготи идеално замишља, свесно се повлачи из „разумног” и „здравог” света - или бар оног који свакодневно инвестира у дотична добра - и урања у сенке иза сцена живота да би од „излизаног камења своје маште изградио свет рушевина." 32 Живи мртваци, вампири, демонске креатуре и незнане силе јесу делирична оруђа унутрашње логике измаштаног света хорора - логике утемељене делом на страху, а делом на морбидном пориву да се сами себи, уз кисели смех, ругамо: „На крају, сасвим извесно, остајемо лутке, и наши осмеси нису ништа мање нацртани. Али бар смо их овлажили својом крвљу."

Држећи у рукама улазницу у нестварно, људска бића су, дакле, кадра да кроче у свет „стварнији од стварног”, свет иза појавне равни, и користе се његовим средствима и атрибутима. Нестварно нас бар на извесно време избављује из оквира „здравог” и „разумног” света и уводи нас у ирационално, морбидно пространство иза сцена живота - где, једном ушавши, стичемо макар ту слободу да се играмо луде и саркастично се церимо сопственим „здравим” и „разумним“ напорима у „стварном” свету. Лиготијево прихватање по живот негативних вредности не иде, међутим, као код Ничеа, у прилог коначној афирмацији живота. Саркастичан смех луде или лутке чији је осмех овлажен властитом крвљу кадар је евентуално да нам омогући катарзу, ментално пражњење у алтернативном свету који је, ако ништа, мање лажан од, како би то Лавкрафт рекао, „бљутаве 'све је у реду

31 Исто, стр. 45.

32 Ligotti, нав. дело, стр. 110.

33 Исто, стр. 111. 
са светом' халуцинације, условљене чистом снагом жеље да то буде тако." ${ }^{\prime 4}$

За разлику од Лиготија, који у неизбежности психичке патње и физичке агоније види доказ да је свеколика егзистенција кошмар и да би органски живот требало да престане да постоји, Ниче сматра да би појединац требало да изгради вољу за патюу, како би последично развио вољу за моћ. Пратећи Шопенхауера, Ниче сматра да је патња доживљај отпора према стремљењима наше воље, те да се моћ састоји у нашем надвладавању отпора и развијању осећаја учинковитости, тачније индивидуалне способности да спољном свету наметнемо властите услове за остваривање наших највиших жеља. ${ }^{35}$ За разлику од Лиготију блиске филозофије песимизма, Ничеова етика моћи поздравља и хвали неизбежност патње у људском животу. Како Реџинстер примећује, „Ниче би сматрао бедном егзистенцију у којој нема никаквог отпора којег би требало савладати, никаквих изазова с којима би требало суочити се - укратко, егзистенцију лишену патње." 36

Лиготи се по свему судећи не би сложио са овако проактивним поимањем целисходног живота најпре због тешких психолошких проблема које трпи од своје седамнаесте године, ${ }^{37}$ а затим и због низа гастроентереолошких тешкоћа насталих као резултат континуираног психичког стреса. Комбинација психичког и физичког бола коју овај аутор проживљава у дугом временском распону вероватно је одговорна за његов дефетистички став према патњи као чињеници људског живота коју је немогуће прихватити, зато што непрестано бива испољена у толико високом интензитету да чини егзистенцију неподношљивом. „Само у нестварном”, према Лиготијевом мишљењу, „можемо бити спасени. Стварност уништава све и свакога." ${ }^{38}$

Ова практична примедба ипак нас примиче за корак ближе пољу вредности за које би се могло констатовати да их Лиготи прихвата, упркос томе што одбацује живот као вредност. Наиме, овај аутор признаје да је „бол његова муза”, те да пише онда када га нешто у животу подстакне на то,

34 Лавкрафт, Х. Ф. Признање неверовања, у: Лавкрафт, приредио Огњановић, Д. (2009), Чачак: Градац, број 171-172, стр. 71.

35 Clark, nav. delo, str. 93.

36 Register, nav. delo, str. 267.

37 Ognjanović, nav. delo, str. 283.

38 We Can Hide From Horror Only In The Heart Of Horror: Notes and Aphorisms by Thomas Ligotti, 10. 05. 2019. http://www.angwa.de/Ligotti/essay/ heartofhorror_e.htm 
„нарочито патња и мржња”. Речени пар сентимената служе као одскочна даска за писање приповетки које нашем аутору помажу да превазиђе његово тренутно, мучно искуство живота и надовежу се на његов шири поглед на свет. ${ }^{39}$ Бављење уметничким стваралаштвом (овде, конкретно, писањем хорора) за Лиготија је, дакле, вредност до које ваља држати, најмање зато што служи као отпустни вентил за негативна осећања, али и због тога што може да послужи као терапеутско средство (с ограниченим учинком). Поред тога, према Лиготијевој процени, „сва добра књижевност утемељена је на непријатном осећању, на врло специфичном утиску мучнине који нас мотивише да поделимо бол с другима." ${ }^{40} \mathrm{Ca}-$ свим је вероватно да у залеђу ових тежњи за дисеминацијом (углавном лоших) осећања кроз прозно хорор стваралаштво стоји идеја о целисходности споја светоназора аутора и читалаца ${ }^{41}$, при чему читалац ступа у контакт са истинама које је одувек слутио, али није желео да их поближе сагледа; док аутор проналази бар ситну утеху у утиску да с тим истинама више није сам, да их је још неко, захваљујући њему, спознао и нашао их естетски, па и филозофски занимљивим - утеху, коначно, која спаја скрајнуте и већини света несимпатичне истомишљенике, које је један (субверзиван?) унутрашњи импулс навео да преиспитају и коначно одбаце доминантне истине религија, митове власти и терапије баналностима и рутинама које нуди свакодневица. Утеха у ужасу је, доиста, за Лиготија „ултимативна, што ће рећи једина утеха”: „Нудесна је то ствар рећи, да се утеха у ужасу у уметности састоји у томе да он заправо оснажује нашу панику, појачава је на разгласу наших ужасом-опустошених срца, подиже страву на најјаче трештање, све време тежећи оној савршеној и заглушујућој амплитуди на којој можемо да играмо уз бизарну музику наше сопствене мизерије." ${ }^{\prime 2}$

Пошто најзад апсорбујемо увид да сваки наш проживљен тренутак, па и онај нама лично најдражи, у себи крије клицу стравичног, ми смо већ на корак од прихватања ужаса као елементарне чињенице стварног. Будући да ту чињеницу, једном кад се у нама обелодани, потом бива немогуће одбацити, преостаје нам само да је признамо као неминовну.

39 Cardin, M. It's All a Matter of Personal Pathology: Interview with Thomas Ligotti, 10. 05. 2019. http://www.teemingbrain.com/interview-with-thomasligotti/

40 Paul, R. F. and Schurholz, K. Triangulating the Daemon: An Interview with Thomas Ligotti, 10. 05. 2019. http://www.ligotti.net/tlo/esoterra.html

41 Упоредити са: Огњановић, нав. дело, стр. 285.

42 Ligoti, T. Utehe u užasu, u: Pisar tame: Život i dela (2017), Novi Sad: Orfelin izdavaštvo, str. 276. 
Један од начина да то успешно изведемо јесте, како Лиготи наговештава, не у страху, који је по много чему близак патњи и болу, него у пароксизму страха и резултујућој егзалтацији која нас подиже изнад свеколиких психичких агонија, у само тајанство одакле страх извире. Нашминкани крвљу и напудерисани прахом с мртвачких костију, ми коначно постајемо слободни, и то не од извесних праначела света, већ од сопствених самообмана по питању тога шта свет јесте - самообмана које нам, између осталог, помажу и да поднесемо сам удес стварности.

Суочавање са језивим наличјем света кроз контемплацију о стравичном блиско је, такође, будистичкој мисли. Будистичка јога познаје метод медитације о нечистом или о нечистоћи тела (asubha bhāvanā) која у монашкој традицији подразумева медитирање над људским лешом у различитим фазама труљења. ${ }^{43}$ Предвиђени исход asubha bhāvanā медитације је тај да код практиканта изазове утисак одбојности према чулним задовољствима која би потом требало да учврсти генералну спознају о ефемерности органског живота, односно о неминовној пролазности како практикантовог тела, тако и, евентуално, оног за којим практикант жуди или чезне или испољава било какву врсту жеље. На дубљем нивоу, уз то, пропадљивост тела указује на несталност света, али и на основни проблем егзистенције, дефинисан у будистичком смислу као патьа: мотрећи леш надут или загнојен или уцрвљан или претворен у скелет, будистички монах замишља сопствено тело како се креће кроз аналогне фазе распадања; и на концу - идеално - увиђа, прихвата и превазилази мизерију света. ${ }^{44}$ Усредсређујући се на помодрели леш који су изгризли црви, јогин обуздава жеђ за бојама, облицима, контактима, частима и настоји да одвоји чула од њихових објеката, тачније од оног запаљивог које храни страсти. ${ }^{45}$

Слично Лиготијевом напудерисаном и нашмиканом пајацу који плеше уз симфонију сопствене беде, и будистички монаси су се традиционално одевали у одоре скројене од претходно опраних, обојених па у огртаче зашивених дроњака скинутих с људских лешева. ${ }^{46}$ Ова семантичка полуција тела

43 Obeyesekere, G. „Buddhism, Depression and the Work of Culture in Sri Lanka“, in: Culture and Depression, eds. Kleiman, A. and Good, B. (1985), Berkley: University of California Press, p. 141.

44 Neri, C. (2008) Tsai Ming-liang and the Lost Emotions of the Flesh, Positions 16:2, Durham: Duke UP, p. 392.

45 Bugault, nav. delo, str. 190

46 Shaw, S. (2006) Buddhist Meditation: An Anthology of Texts from the Pali Cannon, London and New York: Routledge, p. 102. 
МАРКО ПИШЕВ

знаковима смрти и декомпозиције у најмању руку настоји да означи иступање појединца из сфере профане егзистенције у лиминалну област између живота и смрти, у којој је ум изложен халуцинаторном приказивању ужасног. Како код будистичких монаха, тако и код Лиготијевог хорор аутора, коначни исход овог усредређења на стравично је уклањање представа о себи, о својој псеудоличности, свом егу ${ }^{47}$, додуше, с најамање једном битном разликом: док будистичка доктрина тврди да је све нестално, варљиво и у основи празно, Лиготи сматра да излаза из пунине у празнину нема, те да је сама чињеница постојања проклетство за које не постоји лек.

\section{Закључак}

У односу на већину прозних писаца који своје списатељске каријере развијају дуже од три деценије, Томас Лиготи можда није написао много, али оним што јесте објавио до данас, завредео је статус култног писца натприродне страве. Лиготијева високо стилизована проза сардонична је спрам човекове делузије величине у свету који је све сем њему наклоњен.

Његове хорор приче читаоце ослобађају законитости „доброг” света - „срећног” света: сладуњава обланда „разумне” и „здраве” реалности, како нам његова проза поручује, безуспешно се труди да сакрије мрску природу стварности пројектовану на ледено црнило свемира. Стварност је налик дасци положеној преко „гроба без дна”"48 која нас с подмуклим шкрипањем дели од смрти; али, та даска ће кад-тад пући (и то нам је савршено јасно). Термити који се њоме хране су наши кошмари; а приче страве су пукотине кроз које с мештавином страха и фасцинације, завирујемо у слојеве испод.

Из напред изнесених Лиготијевих ставова видимо да је за овог аутора сваки облик свесности страшнији од смрти. С друге стране, суицид Лиготију делује једнако бесмислен као и живот: све и кад би сакупио довољно снаге да га изведе, самоубилачки чин из његовог угла не би успео да пружи задовољавајући излаз из проблема. ${ }^{49}$ Ово становиште је,

47 За Лиготија савршени свет би био онај у којем су сви искусили смрт свог ега. Види интервју на страници: http://www.teemingbrain.com/interviewwith-thomas-ligotti/

48 Фраза преузета из наслова збирке прича Емброуза Бирса: Бирс, Е. Гроб без дна (2008), Београд: Логос.

49 Cardin, M. It's All a Matter of Personal Pathology: Interview with Thomas Ligotti, 10. 05. 2019. http://www.teemingbrain.com/interview-with-thomasligotti/ 
сасвим могуће, резултат његових уверења о метафизичкој природи стварности: могућност инверзије смрти у један дубоко поремећен облик трајања који се протеже у бескрај био би улазак из једне у другу, овог пута финалну, замку. Вечност је клопка, јер се у њој крију наговештаји туђинске егзистенције исувише велике да би се обухватила умом егзистенције која вреба у наказном наличју ствари. Она је симболички повезана с кошмарним, зато што кошмар - нарочито у крајње апстрактној форми - често и сам делује као фрагмент нечег несагледиво великог. ${ }^{50}$

Будући да је за Лиготија свет манипулација а стварност привид, само завеса, иронично набачена на прави смисао ствари, ми логику његових прича, нарочито оних најбољих, можемо да меримо искључиво аршинима врло вивидних и неугодних снова. Упркос томе што нису логични, ми осећамо да ти снови носе у себи неку врсту истине. Слично је и са порукама за којима Лиготи посеже и преноси их из дубине амбиса: оне су загонетне, недокучиве и састоје се најпре у пажљиво нанизаним појединостима, у акумулацији детаља, чија целина коначно превазилази оквире нашег ума или бар његовог свесног дела.

Натприродно зло у Лиготијевој прози нужно је посматрати онтолошки - као да је иманентно свету. Оно, другим речима, не мора да има никакве везе са неким конкретним скупом моралних вредности - нити са повредом у њих учитаних стандарда: оно може бити, а како његове хорор приче дочаравају често $и$ јесте, пуки апсурд. Феномен зла у Лиготијевој прози не може се, дакле, свести на зло по себи (ма колико широко га дефинисали), већ првенствено на страх. Посредством страха, зло урања у регистар кошмара у којем је све могуће и страва се отискује даље, ка врхунцу.

Да би изазвала страх, сабласна, натприродна претња, онда, не мора нужно да буде аморална, већ може да напросто функционише у складу са неким поремећеним, па и недокучивим унутрашњим критеријумом. Прикаже ли се у виду апсурда, она се најчешће испољава ван уобичајено дефинисаних вредносних оквира, а застрашујућа је управо зато што евоцира осећај нечега далеко већег од онога што је непосредно приказано. Зло плаши најпре зато што је непознато, а потом и зато што остаје до краја неодгонетљиво. Оно је тајанство које успева да заведе и у себе апсорбује јунака; самим упливом у стварност и упорним одбијањем да се на пољу значења фиксира у конкретан спектар значења, оно буди фасцинацију и страх.

50 Упоредити ca: Santilli, нав. дело, стр. 182-184. 
Лиготијев хорор наступа са премисом да је свет зло (отуд толико бола, зверстава и ужаса у свету), а да је живот гнусна, апсурдна фарса у коју смо колективно хипнотисани да верујемо. Његове „хорор измишљотине и фантазмагорије” заправо су уметнички поступци чије се претензије крећу у правцу раскринкавања те фарсе: што је хорор лиричнији, когнитивно сложенији и метафизички дубљи, његова стравична порука човеку више је продорна (али и више фасцинантна, јер ту читалац ступа у додир са „забрањеном”, „ненормалном", културно табуисаном природом спознаје ${ }^{51}$ ).

Коначно, човек се никада не осећа више удаљен од „ближњег свог”, више сам него у страху. На субјективном плану, ми ступамо у контакт са другим особама кроз вербалну и невербалну комуникацију. Али целину страха је немогуће исказати, гестом или речима, свеједно: она се на једном нивоу може провриштати, очитати на лицу и кроз дрхтаје тела, али за особу покрај нас ће том приликом тек присуство страха постати откривено, док ће садржај остати скривен. Страва према нама испољава веома крупне захтеве: она тражи нашу интимну блискост, наше поверење и пуну пажњу - и најчешће успева да испуни свој циљ, са ванредном лакоћом. Лиготијев хорор препознаје и користи овај интимни квалитет страха. Ово постиже управо зато што „проговара” кроз механизме заплета ирационалним језиком. Слично незгодном, унапред уговореном венчању - где једна страна ликује, а друга пати - страх у натприродном хорору Томаса Лиготија дифузно лебди око одабране жртве, паралише је пред свадбеним олтаром и напокон прождире у првој брачној ноћи. Преузевши улогу праоца сваког чврстог савеза, страх увиђа зашто је баш ту где јесте. И нема ли разлога да поверује да ће блискост са његовим одабраником или одабраницом, ма колико нежељена, одбојна и болна, ипак трајати, не „док их смрт не растави", већ и након тога?

\section{ЛИТЕРАТУРА:}

Aickman, R. Introduction, in: The 3rd Fontana Book of Great Ghost Stories, ed. Aickman, R. (1966) Glasgow: William Collins Sons \& Co.

Aickman, R. (1966) The Attempted Rescue, London: Gollancz.

Бирс, Е. (2008) Гроб без дна, Београд: Логос.

Borg, M. B. (1988) The Problem of Nihilism: A Sociological Approach, Sociological Analysis, vol. 49: 1, Oxford: Oxford University Press, pp. 1-16.

51 Pišev, M. (2016) Horor i zlo, Etnoantropološki problemi, Beograd: Odeljenje za etnologiju i antropologiju Filozofskog fakulteta, str. 333. 


\section{МАРКО ПИШЕВ}

Bugault, G. Mistika indijskog budizma, u: Enciklopedija mistika II svezak, priredila Davy, M. M. (1990), Zagreb: Naprijed.

Clark, M. (2012) Suffering and the Affirmation of Life, Journal of Nietzsche Studies, Vol. 43, No. 1 University Park: Penn State University Press.

Cross, S. (2013) Schopenhauer's Encounter with Indian Thought: Representation and Will and their Indian Parallels, Honolulu: University of Hawai'i Press.

Doomen, J. (2012) Consistent Nihilism, The Journal of Mind and Behavior, Vol. 33, No. 1/2, New York: Institute of Mind and Behavior, Inc.

Лавкрафт, Х. Ф. Признање неверовања, у: Лавкрафт, приредио Огњановић, Д. (2009), Чачак: Градац, број 171-172.

Ligoti, T. Utehe u užasu, u: Pisar tame: Život i dela (2017), Novi Sad: Orfelin izdavaštvo.

Ligotti, T. (1994) Noctuary, New York: Carrol \& Graff, Inc.

Ligotti, T. (2012) Songs of a Dead Dreamer (e-book).

Neri, C. (2008) Tsai Ming-liang and the Lost Emotions of the Flesh, Positions 16:2, Durham: Duke UP.

Niče, F. (2012) Volja za moć: pokušaj preocenjivanja svih vrednosti, Beograd: Dereta.

Obeyesekere, G. Buddhism, Depression and the Work of Culture in Sri Lanka, in: Culture and Depression, eds. Kleiman, A. and Good, B. (1985), Berkley: University of California Press.

Ognjanović, D. (2015) The Greatest Old One, Toronto: Rue Morge, no. 161 .

Ognjanović, D. Tomas Ligoti: Iz dubine najcrnjeg ambisa, u: Pisar tame: život i dela (2017), Novi Sad: Orfelin izdavaštvo.

Pišev, M. (2016) Horor i zlo, Etnoantropološki problemi, Beograd: Odeljenje za etnologiju i antropologiju Filozofskog fakulteta.

Pišev, M. (2018) Islam, relativizam i nauka, Beograd: Filozofski fakultet i Dosije studio.

Reginster, B. (2006) The Affirmation of Life: Nietzsche on Overcoming Nihilism, Cambridge: Harvard University Press.

Santilli, P. (2007) Culture, Evil and Horror, The American Journal of Economics and Sociology, Vol. 66, No. 1, New Jersey: American Journal of Economics and Sociology, Inc.

Shaw, S. (2006) Buddhist Meditation: An Anthology of Texts from the Pali Cannon, London and New York: Routledge.

Šopenhauer, A. (1981) Svet kao volja i predstava, Beograd: Grafos. 
МАРКО ПИШЕВ

\author{
Marko Pišev \\ University of Belgrade, Faculty of Philosophy - \\ Department of Ethnology and Anthropology, Belgrade
}

THE ONEIRIC DEFILING OF REALITY

\title{
THOMAS LIGOTTI'S SUPERNATURAL HORROR
}

\begin{abstract}
Practically from its inception, the Enlightenment ideal of rationality was equally criticized and fostered in European intellectual tradition. The belief in reason as an exclusive property of human mind capable of reproducing an authentic image of reality quickly revealed itself as highly disputable from the standpoint of philosophy and art, as well as from the angle of particular scientific disciplines (above all, psychology and anthropology). Within the sphere of contemporary literature, one of the greatest adversaries of the Enlightenment idea of the rationally apprehensible nature of reality is the horror fiction writer Thomas Ligotti. For this author, "the world as it is" has little or nothing to do with rational consciousness, and correlates more strongly with our deepest irrational fears which reveal themselves in feverish visions and nightmarish images. While establishing his personal and artistic worldview on the inversion of the usual ideas about reality, Ligotti creates a specific type of subversive prose: one that depraves the world of any higher meaning and denies all possibilities of consolation to humankind. In this paper I pose the question whether such disillusionment may leave any possibility for an individual to act independently, be it in a subversive or non-subversive sense of the word.
\end{abstract}

Key words: Thomas Ligotti, supernatural horror, individual, reality, nightmare, nihilism 